\title{
PROPERTY PRICES, HOUSING POLICIES FOR COLLATERAL AND RESALE CONSTRAINTS
}

\author{
Eddie C. M. HUI a,*, Jiawei ZHONG, Kahung YU a \\ ${ }^{a}$ Department of Building and Real Estate, The Hong Kong Polytechnic University, Hong Kong, China
}

Received 28 May 2015; accepted 22 August 2016

\begin{abstract}
The question of whether significant impacts of Loan-to-value (LTV) ratio and Special Stamp Duty (SSD) on residential property market prices exist has been hotly debated. This study aims to investigate the long-term and short-term impacts of LTV ratio and SSD on property prices in Hong Kong. In the study period, the interest rate is low, and the growth rate of housing mortgage is slower than the growth rate of market prices. The findings indicate that changes in LTV ratio cannot change the potential purchasers' willingness to purchase housing flats over the past ten years. SSD, on the other hand, only have a more prominent long-term impact on larger properties (more than $70 \mathrm{~m}^{2}$ ) by directly reducing the transaction volumes, compared with that on smaller (less than $70 \mathrm{~m}^{2}$ ) ones.
\end{abstract}

KEYWORDS: Loan-to-value ratio; Special Stamp Duty; Residential property prices; Error correction model

\section{INTRODUCTION}

To discuss the economic influence of the Loan-tovalue ratio and Special Stamp Duty on the property market, it is necessary to illustrate the background as to why the government tries to utilize these tools in attempt to suppress the rapid rising market prices in Hong Kong.

As a highly developed metropolis in Asia, Hong Kong is popular among immigrants as a residential choice. On the one hand, the completeness of legal, education, and medical treatment systems attracts foreigners to move to Hong Kong. Meanwhile, in attempt to stimulate the economy, the US Federal Reserve has adopted the quantitative easing policy, in turn increasing money supply in the U.S. and hence depreciating the value of USD. This means that the Hong Kong Dollar, which is pegged to the USD, has also depreciated. At the same time, the Chinese government also introduced its own quantitative easing policy in 2009, which has been found to be an important determinant in the growth of real estate investment in Mainland China (Wei et al. 2014). Lower mortgage interest rate and HKD exchange rate enhance the investment potential of the property market,

* Corresponding author. E-mail: bscmhui@inet.polyu.edu.hk which makes residential properties more attractive to both local and non-local residents.

As a result of high demand by local and immigrant potential house purchasers, the average price of private property markets has encountered a rapid rise since 2008. At present, the average property price is almost twice as much as that in 2007 (Fig. 1).

Although the Hong Kong government can control the housing supply by modifying the existing land supply policies (e.g. lease conditions) (Hui 2001;

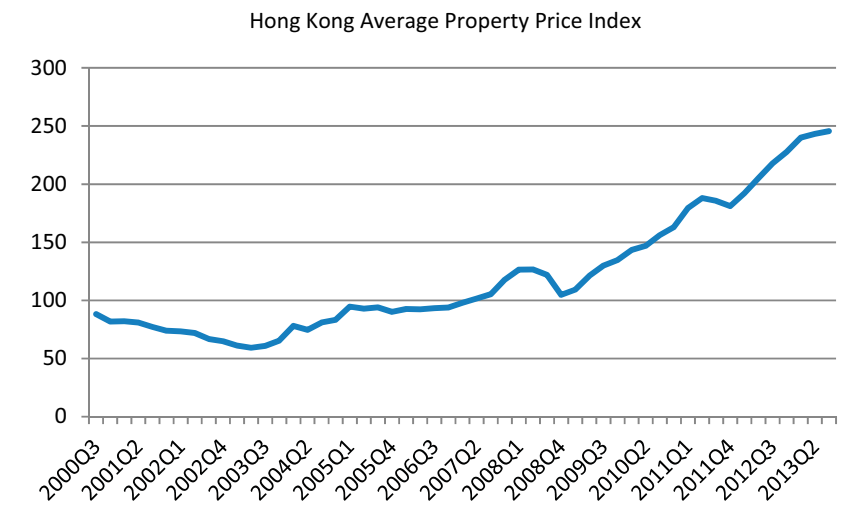

Fig. 1. Hong Kong average property price index (for private residential housing)

Source: Hong Kong monthly digest of statistics, by Census and Statistics Department. 
Hui, Soo 2002; Hui et al. 2006) and by increasing the supply of public housing (i.e. re-launching the Home Ownership Scheme), these measures cannot suppress the booming market in the short term. Therefore, measures have been adopted to curb short-term resale activities. On November $20^{\text {th }}$ 2010, a new tax called Special Stamp Duty (SSD) was introduced (Fig. 2). Individuals or companies that resell private housing unit(s), purchased after November $20^{\text {th }} 2010$, within two years are subject to additional tax payable to the government. The tax rate was adjusted in October 2012 (Table 1).

Besides the regular SSD, since October 2012, foreign investors have been charged with an additional SSD of $15 \%$ of the property value. Then, from February 2013 onwards, for households who have already possessed one property, they have to pay twice as much in stamp duty for properties with transaction prices of over 2 million HKD (in fact over $80 \%$ private housing departments in market exceed this standard), whereas that for properties with transaction prices of less than 2 mil-

Table 1. The rate of Special Stamp Duty in Hong Kong When the property was purchased between 20 November 2010 and 26 October 2012

\begin{tabular}{ll}
\hline Holding period before the resale & Tax rate \\
Within 6 months & $15 \%$ \\
After 6 months but within 12 months & $10 \%$ \\
After 12 months but within 24 months & $5 \%$ \\
\hline When the property was purchased after 27 October 2012 \\
\hline Holding period before the resale & Tax rate \\
Within 6 months & $20 \%$ \\
After 6 months but within 12 months & $15 \%$ \\
After 12 months but within 24 months & $10 \%$ \\
After 24 months but within 36 months & $5 \%$ \\
\hline
\end{tabular}

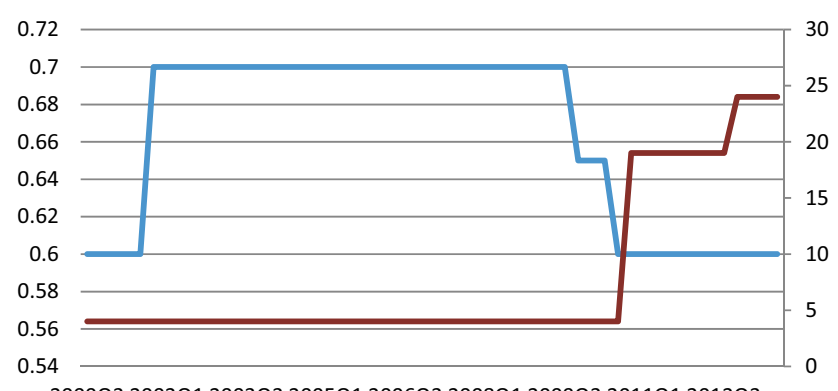

2000Q3 2002Q1 2003Q3 2005Q1 2006Q3 2008Q1 2009Q3 2011Q1 2012Q3

Loan-to-value ratio limit _highest marginal stamp duty rate

Fig. 2. Loan-to-value ratio limit (average, left-scale) and highest marginal stamp duty rate (right-scale, \%)

Source: Hong Kong Monetary Authority.

Note: Special Stamp Duty is added on the normal stamp duty when resold within 2 years before Oct 2012, within 3 years afterwards. lion HKD would be $1.5 \%$ of the transaction price. SSD is supposed to be levied only on short-term transactions, which is regarded as one of the main triggers of the recent property price rises in some government officials' opinions.

The Special Stamp Duty is charged on top of the current price-related stamp duty on residential properties. Stamp duty, a type of tax levied on documents, is not rare in modern economics. In Hong Kong, stamp duties are chargeable for four types of economic activities, including the sale or lease transactions for local immovable properties, as well as the transfer of Hong Kong stocks, Hong Kong bearer instruments, and any duplicates and counterparts of documents for the above activities. It works mainly as a regulatory measure by the government, to either encourage or discourage certain economic activities. For example, in the stock market, the government may raise the rate of stamp duty to discourage securities transactions when it believes that the market is overheating. Meanwhile, the Special Stamp Duty, which appeared first in Singapore, is different from the normal stamp duty, in that it is only applicable to short-term transactions.

Singapore introduced the SSD (named Seller's Stamp Duty, only imposed on seller's side) in three phases. In the first phase (Feb 20 $0^{\text {th }}, 2010-$ Aug $29^{\text {th }}, 2010$ ), those who resell their properties within one year of purchase would have to pay the same amount of stamp duty (or the same tax rate) as the buyers do. The resellers have to pay $1 \%$ of the resale price for the first $\$ 180,000,2 \%$ for the next $\$ 180,000$ (the amount over $\$ 180,000$ but below $\$ 360,000$ ), and $3 \%$ for the rest (the amount over $\$ 360,000$ ). In the second phase (Aug 30 th $, 2010-J a n ~ 13^{\text {th }}, 2011$ ), resellers still have to pay the same amount of stamp duty as the buyers within one year. When the holding period is over 1 year but less than 2 years, the amount of seller's stamp duty is reduced to $2 / 3$, compared to the case of reselling the property within one year. This proportion is further reduced to $1 / 3$ if the holding period is over 2 years but less than 3 years. However, in these two phases, the increasing trend of property prices was not slowing down. Finally, the Singapore government announced the third phase on Jan $14^{\text {th }}, 2011$. The government would charge $16 \%, 12 \%, 8 \%$, and $4 \%$ of the amount of the property value in a resale transaction if the property is disposed of within 1 year, after 1 year but within 2 years, after 2 years but within 3 years and after 3 years but within 4 years respectively, from the acquiring day of the last purchase. Hong Kong's SSD policy is largely similar to Singapore's SSD policy. 
Whether or not the SSD is effective in curbing the rise in property prices has been widely debated. In the six months following the introduction of the SSD the property price index had risen from 163.7 to 185.9. Many Hong Kong citizens suspected that SSD did not play an important role in slowing down the increasing housing price trend. By contrast, the Asian and Pacific Department of the International Monetary Fund (IMF) has conducted a research study on the policy influence on Hong Kong's property market, with the emphasis on the SSD and Loan-to-value ratio (Craig, Hua 2011). The authors insist that, after considering the comprehensive demand-supply related factors, the introduction of SSD can still generate a shortterm impact on property prices.

Another important financial tool for regulating property transactions is the Loan-to-value (LTV) ratio, which is the proportion of mortgage loans offered by a bank to property purchasers compared with the total value of the properties. LTV ratio, a type of targeted credit policy measure, is a collateral constraint offered by banks to avoid moral hazard and adverse selection from borrowers. Since the mortgage loan itself is not sufficient to cover the full transaction price of a housing unit, a down-payment from home purchasers is thus required. The LTV ratio is usually more important for first-time buyers (FTB) in the UK. In the 1990s, the LTV ratio was up to $90 \%$. However, it fell to $75 \%$ in the aftermath of the financial crisis and the subsequent mortgage contraction which is believed to have further deteriorated the local property market. In November 2011, the UK government announced the stimulating policies, one of which included an increase in the LTV ratio for FTB to 95\%. Meanwhile, the US banks still maintains a high LTV ratio to alleviate the housing burden for citizens, even after the mortgage crisis in 2008, the LTV ratio has reduced slightly from $96.5 \%$ to $95 \%$. Generally speaking, the LTV ratio reflects the government's encouragement to home purchase, and is an important tool to adjust the residential property market.

In the $21^{\text {st }}$ Century, the Hong Kong government has thrice changed the requirement of LTV ratio. In October 2001, the LTV ratio for the purchase of luxury properties (with a value of more than 12 million HKD) increased from $60 \%$ to $70 \%$ (Fig. 2). When the demand in property market continued to rise, the LTV ratio for the purchase of properties with a value of over 20 million HKD returned to $60 \%$ in October 2009; and by August 2010, the LTV ratio for the purchase of properties with a value of over 12 million HKD (and be-

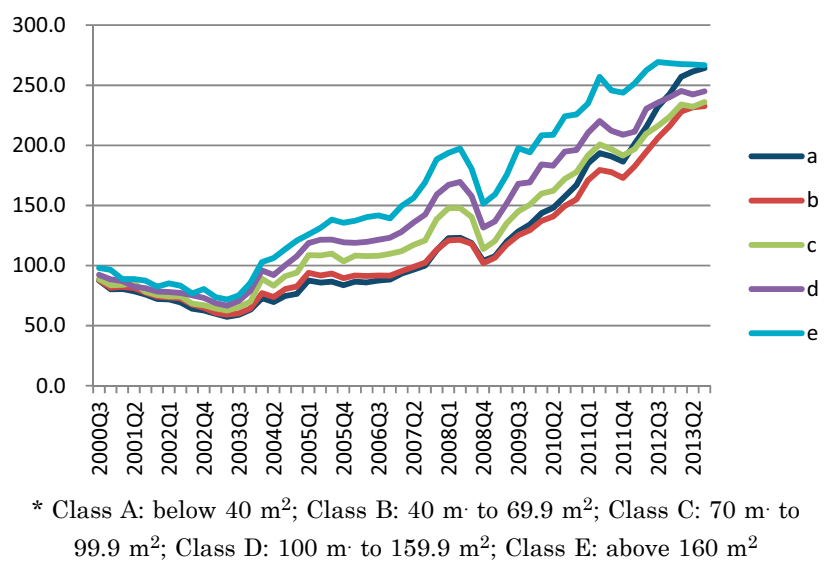

Fig. 3. Price indices of private residential properties in different sizes

Source: Hong Kong Monthly Digest of Statistics, by Census and Statistics Department in HKSAR.

low 20 million HKD) also dropped to $60 \%$. All the changes can be explained as the government would like to control the mortgage risk for luxury properties. Most people believe that the transactions for smaller apartments (less than $70 \mathrm{~m}^{2}$ ) are seldom affected by the amendments.

However, the price movements of residential properties of different sizes may vary. The price index of luxury apartments with the largest floor area (Class E, over $160 \mathrm{~m}^{2}$ ) has increased from 139.2 to 243.8 in the previous five years (Fig. 3, the baseline in 1999 is set to be 100), while the prices of the two mass apartment classes, Class A (below $40 \mathrm{~m}^{2}$ ) and Class B $\left(40 \mathrm{~m}^{2}\right.$ to $\left.69.9 \mathrm{~m}^{2}\right)$, have nearly doubled during the same period, from 88.4 to 186.5 (Class A) and from 91.6 to 172.9 (Class B). It is possible that the SSD has not exerted the same pressure on prices of properties in different submarkets.

This study comprises the following sections. Section 2 reviews relevant previous literature on LTV ratio and SSD and their respective influences on property prices, followed by a discussion of methodologies used for the analysis. The third section illustrates the data set, the Error Correction Model, and the event study utilized in this study. Section 4 discusses the empirical findings, which presents a more integral discussion over the impacts of LTV ratio and SSD on property prices in different housing submarkets. Finally, a concluding remark will be given.

\section{LITERATURE REVIEW}

This section illustrates the previous studies which have explored the influences of LTV ratio and SSD on property prices. Both policies are 
classified as macro-prudential policies, to be differentiated from the usual monetary and fiscal policies. These policies aim to change the investors' market expectations only, as their expectations are usually different from potential homeowners' (Wong et al. 2005). Previous studies have developed special housing market models, highlighting the effect of Loan-to-value ratio on property prices (Stein 1995; Ortalo-Magné, Rady 2006). It is found to be effective in reducing the systemic risk in the property market cycles (Wong et al. 2011). The results found by Immergluck and Smith (2005) show that subprime lending lead to higher rates of foreclosures than prime lending, which in turn indicates the importance of financial constraints. Basically, a lower LTV ratio would require a larger down-payment from homebuyers, and, in theory, usually render them less willing to purchase new houses. Even when other economic conditions are kept constant, under different LTV ratios, transaction volumes would decline more when significantly negative news occurs, since more households would find themselves with negative equity as housing prices fall (Stein 1995). Goodhart and Hofmann (2007) suggest that the LTV ratios should be lowered when the mortgage growth is booming. The existence of LTV ratio would also create a price change besides income changes and changes in first home purchasers' demand (Lamont, Stein 1999; Benito 2006; Ortalo-Magné, Rady 2006; Kuttner, Shim 2013). Claessens et al. (2013) believe that LTV ratios can reduce banks' leverage and non-core to core liabilities growth when the market is booming, which can mitigate financial system vulnerabilities. Other theories relevant to the financial constraint concern nominal loss aversions (Genesove, Mayer 2001). In short, the LTV ratio is often viewed as a tool to stabilize the property market (Crowe et al. 2013; Kuttner, Shim 2013).

SSD, as seen in both Hong Kong and Singapore, which focuses on the duration between two transactions for the same apartment, has not been widely adopted in other countries. Most developed economies would not choose to introduce SSD to limit the holding period of the transactions. Previous researches have focused on the effect of normal stamp duty, or "transfer taxes", on the market functions in the real estate area. Benjamin et al. (1993) point out that, falling housing price, in the short-run, is a response to changes in transfer tax. Dachis et al. (2012) also investigate changes in the Land Transfer Tax in Toronto. Credible evidence suggesting the downside distor- tion to both transaction volumes and transaction prices as a result of the imposition of Land Transfer Tax are found. A comprehensive study about the property transaction tax in the UK has been conducted to illustrate its significant downside pressure on the transaction volumes and market prices (Best, Kleven 2012). This study also reports the stimulating effect of the stamp duty holiday. In general, the rate of traditional stamp duty (or transfer tax) is believed to be negatively related to market prices.

Several working papers have discussed the effects of SSD on speculation activities as well as on market prices in Singapore and Hong Kong. For instance, Lo (2011) agrees with the notion that short-term speculative activities would be expected to be fewer due to higher cost of reselling within 24 months, with transaction volumes reduced. Craig and Hua (2011), using an Error Correction Model, only find a small short-term effect of SSD on housing price. They explain that this small effect would initially push up property prices, which then fall as transactions decrease. Ahuja and Nabor (2011), applying the VAR method, conclude that the introduction of SSD, in order to reduce speculative activities, has no significant influence on both the appreciation rate of housing prices and transaction volume. As the first country to introduce the SSD, Singapore's case has also been in hot debate. Using the event study method, Lo (2011) finds that even though the SSD does reduce the transaction volume of housing in Singapore, it does not curtail the rapid appreciation in housing prices. Kuttner and Shim's (2013) study, with cross-country panel data, concludes that, while housing-related taxation (including SSD) helps slow down housing price growth, a tax reduction does not play a discernable role in affecting housing prices.

However, previous studies on SSD and LTV ratio have focused on the response of the whole housing market, which may overlook the latent differences in the responses to this policy from different parts of the property market. For the submarkets divided by unit size, the growth rates of market prices are different before the announcement of SSD and the changes in LTV ratio, which indicates that the market responses may not be homogeneous. Moreover, the different levels of maximum LTV ratio for different sizes of properties should be viewed as an important reason to discuss the impact of LTV ratio on individual housing submarkets (categorized by unit size).

Several other economic factors are usually regarded as crucial deterministic variables for 
housing prices. For instance, Hui and Gu (2009) find that, as an important indicator of affordability, household income affected the price level in the demand side in Guangzhou. Case and Shiller (2003) prove that in the US, personal income percapita could completely explain the appreciation of properties in most states. By contrast, land supply can contain the increasing trend of housing prices on the supply side (Glindro et al. 2008). A measurable dampening effect is found to exist when the government provides more land for private housing (Lum 2002). The impact from interest rate could be more complex in the Hong Kong property market. A negative correlation between interest rates and housing prices is found from 1989 to 1997 , however, lower interest rate does not lead to higher housing prices during the contraction period between 1998 and 2001 (Wong et al. 2003). Household income or GDP, interest rates, construction costs, mortgage amount have been used as determinants of property prices in many macroeconomic studies (Chen, Patel 2002; Engle, Granger 1987; Dipasquale 1999; Wang et al. 2012; Chen et al. 2012).

\section{DATA AND METHODOLOGY}

\section{Data description}

This study aims to test the influence of the LTV ratio and SSD policies, as well as other macroeconomic variables, on the transaction prices of residential properties. The observation period is from the $3^{\text {rd }}$ quarter of 2000 to the $3^{\text {rd }}$ quarter of 2013. As for the data of the selected macroeconomic variables, real GDP per capita, and usable floor area for newly completed housing are extracted from the Hong Kong Monthly Digest of Statistics, published by the Census and Statistics Department in HKSAR. The building works tender price index is obtained from the Architectural Services Department in HKSAR. Real interest rate and the residential property mortgage are compiled from the Hong Kong Monetary Authority.

As the most important economic statistics related to property market prices, the general trends for real interest rate, real GDP per capita, residential property mortgage, building works tender price index, and usable floor area for newly completed housings (UFA) are shown compared with the property price index (Fig. 4). Land supply, used in the IMF study as an indicator of future housing supply, had fluctuated frequently in 2002-2011 (even equaled to 0 in some quarters).
And as property developers can delay the building plan by one to two years, land supply is thus not a precise indicator for quarterly housing price changes. Instead, the UFA is taken as the housing supply indicator.

The most frequently-used macroeconomic factors in studies of housing prices are interest rate and GDP (or household income if possible). Interest rate would determine the amount of mortgage interests payable to the banks and hence the demand for housing. Household income is found to be the most important driving force of property prices in some studies (Chen, Patel 2002). However, as monthly or quarterly household income data is not available in Hong Kong, GDP is used as a proxy of the household income instead.

The amount of residential mortgages indicates the capital supplied by the banks for home purchases, which is another important factor affecting market prices. In this study, the quarterly total amount of residential mortgages is used as an explanatory variable.

Construction cost has usually been included in previous studies as a determinant on the supply side (Chen, Patel 2002; Wang et al. 2012; Chen et al. 2012). In this light, the building works tender price index (BWTPI), which reflects the tender prices for building services installations in new building works undertaken by the Architectural Services Department, is selected as a proxy for construction cost adjustments over time.

Though controlling land supply is one of the major ways to affect the supply side of the housing market by the government, it is not a direct predictor of property prices as mentioned above. Rather, the usable floor area of newly completed residential housing (UFA) is used, instead, to accurately depict the newly supplied apartments and apartments to be supplied in the future. This indicator would directly influence purchasers' choices and their expectations towards future price changes, and hence the current transaction prices.

Figure 4 shows that property price rises when GDP per capita, residential properties mortgage, and BWTPI increase. By contrast, real interest rate and UFA move towards the opposite direction under similar conditions.

The above five time-series sequences have been chosen and transferred as potential indicators (Table 2). Some of them are introduced to control their possible influences on property market prices. The basic statistics of these sequences are listed in Table 3. 


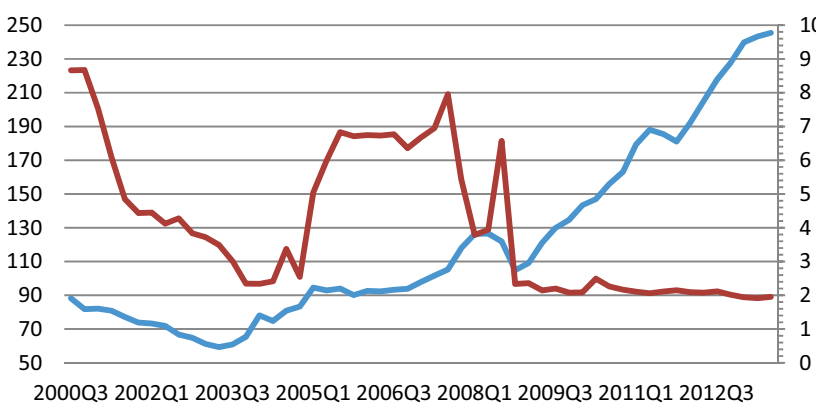

$\longrightarrow$ Price Index $\quad$ Real Interest Rate

(a) Property price index (left-scale) and

Real interest rate (right-scale, \% p.a.)

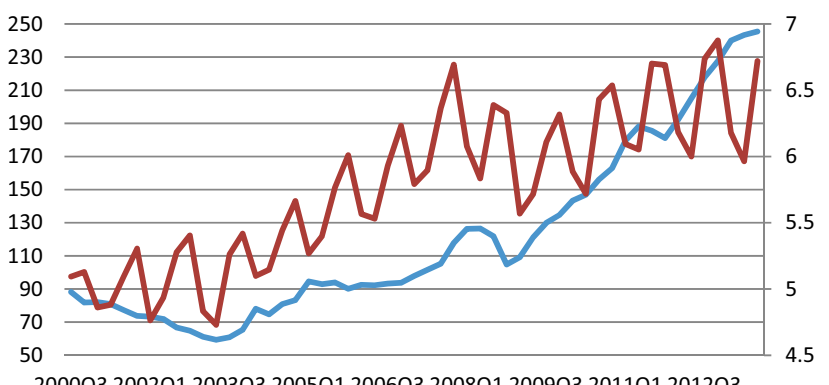

200003200201200303200501200603200801200903201101201203

Price Index Real GDP per capita

(b) Property price index (left-scale) and Real GDP per capita (right-scale, '0000 HKD)

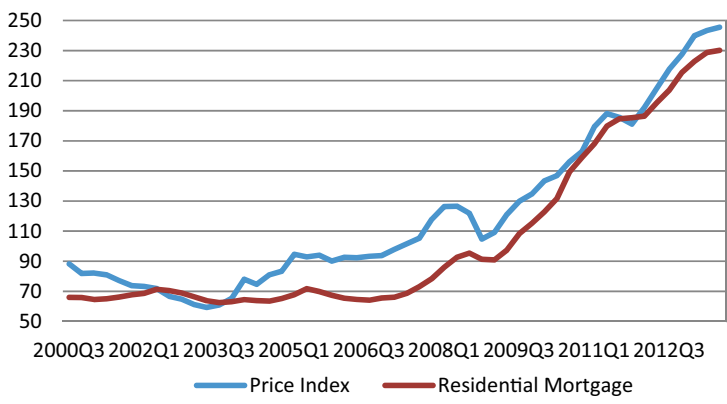

(c) Property price index (left-scale) and Residential mortgage (right-scale, HKD)

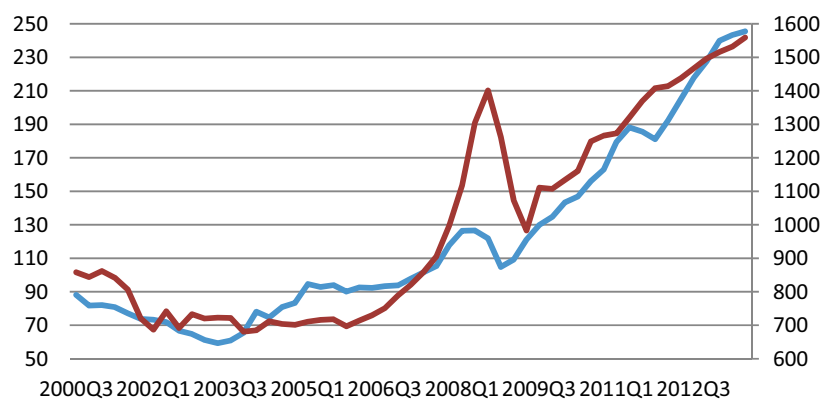

$\longrightarrow$ Price Index $\longrightarrow$ BWTPI

(d) Property price index (left-scale) and BWTPI (right-scale)

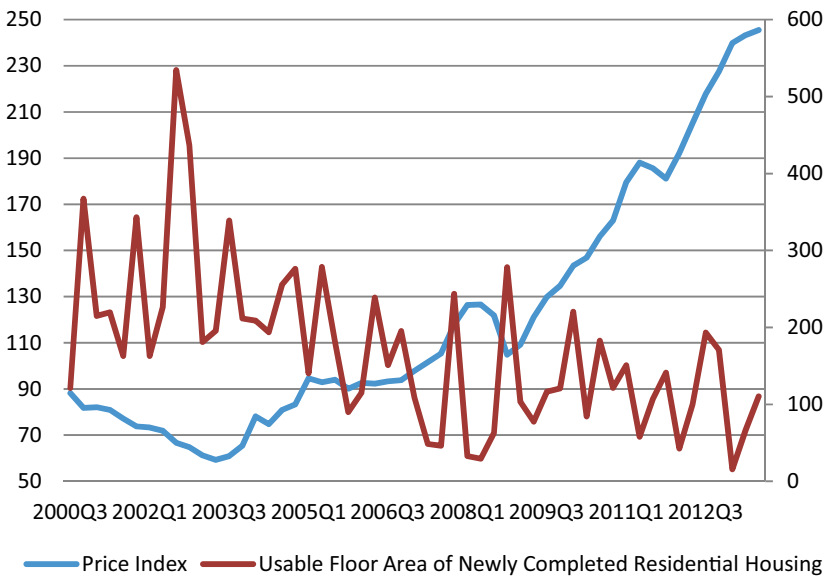

(e) Property price index (left-scale) and

Usable Floor Area of newly completed residential housing (right-scale, '000 m²)

Fig. 4. Trends comparison among Property Price Index and other potential factors

Source: Hong Kong Monthly Digest of Statistics, by Census and Statistics Department in HKSAR.

tect the long- and short-term effects of LTV ratio policy and SSD, as well as other selected variables, on property prices. In addition, an event study approach is also to be conducted to examine the short-term impacts of LTV ratio policy and SSD on different property sub-markets.

\section{Error Correction Model}

In the studies of deterministic factors for property prices, the Error Correction Model has often been used. This model can describe the long-term equilibrium and short-term dynamics of macroeconomic factors on residential market prices (e.g. Adams, Füss 2010). For example, household disposable income levels and interest rates, which

This study would apply both an error correc- 
Table 2. Description of time-series sequences in this study

\begin{tabular}{|c|c|}
\hline Sequence name & Description \\
\hline Real interest rate (\%) & $\begin{array}{l}\text { Deflated monthly HIBOR }+2 \% \text { at the end of each quarter, which is taken as a refer- } \\
\text { ence rate of residential mortgage }\end{array}$ \\
\hline $\begin{array}{l}\text { Real GDP per capita ('0000 } \\
\text { HKD) }\end{array}$ & $\begin{array}{l}\text { Deflated seasonal GDP, which has been divided by Hong Kong population at the same } \\
\text { period }\end{array}$ \\
\hline $\begin{array}{l}\text { Real residential properties } \\
\text { mortgage (millions of } \mathrm{HKD})\end{array}$ & Deflated seasonal total mortgage for private residential properties \\
\hline BWTPI & Building Works Tender Price Index (1999 as the base line) \\
\hline $\begin{array}{l}\text { Usable floor area of newly } \\
\text { completed residential Housing } \\
\text { (thousands of } \mathrm{m}^{2} \text { ) }\end{array}$ & Quarterly usable floor area of newly completed residential housing \\
\hline Loan-to-value ratio & $\begin{array}{l}\text { The LTV ratio was raised in Oct } 2001 \text { once, then lowered twice in Oct } 2009 \text { and Aug } 2010 \text {, } \\
\text { back to the standard before Oct } 2011 \text {. For any quarter, a dummy variable is set to be } \\
\text { equals to }-1 \text { when the LTV ratio was raised once within the past } 12 \text {-month, } 0 \text { when never } \\
\text { changed, } 1 \text { when the LTR ratio was decreased once within the past } 12 \text {-month, } 2 \text { when it } \\
\text { was decreased twice within the past } 12 \text {-month. In the case of Hong Kong, this variable } \\
\text { does not take the other values. The larger absolute number indicates the greater changes } \\
\text { of LTV ratio. }\end{array}$ \\
\hline Special Stamp Duty & $\begin{array}{l}\text { The SSD was introduced three times in November } 2010 \text {, October } 2012 \text {, and February } \\
2013 \text { (only for the households who have held one property). For any quarter, a dummy } \\
\text { variable is set which equals to } 0 \text { when SSD was not changed within the past } 12 \text {-month, } \\
1 \text { when new SSD was introduced once within the past } 12 \text {-month, } 2 \text { when new SSD was } \\
\text { introduced twice within the past } 12 \text {-month. The larger number indicates the greater } \\
\text { changes of SSD. }\end{array}$ \\
\hline
\end{tabular}

Table 3. Basic statistics for the logarithm of time-series sequences in this study

\begin{tabular}{lllll}
\hline Sequence name & Maximum & Minimum & $\begin{array}{c}\text { Mean } \\
\text { deviation }\end{array}$ & $\begin{array}{c}\text { Standard } \\
\text { devion }\end{array}$ \\
\hline Real interest rate * & 17.4021 & -11.2760 & 7.4707 & 8.7840 \\
Real GDP per capita & 6.8762 & 4.7296 & 5.7716 & 0.5865 \\
Real residential properties mortgage & 13.7162 & 13.1771 & 13.3256 & 0.1793 \\
BWTPI & 7.3518 & 6.5236 & 6.8622 & 0.2868 \\
Usable floor area of newly completed residential housing & 6.2813 & 2.7408 & 4.9336 & 0.7051 \\
\hline
\end{tabular}

* Real interest rate doesn't take the logarithm refer to previous researches.

can determine the average mortgage amount for a household, are proved to represent the housing demand schedule and hence the equilibrium price (McQuinn, O'Reilly 2008). Ho and Kwong (2002) discussed the relationship between speculative activities and property price in Hong Kong, and found that while changes in property price can cause speculation activity, the opposite does not hold. Du et al. (2011), deploying the ECM, suggest that the bi-directional Granger causalities between housing prices and land prices in China exists in the long term, but in the short term, only onedirectional Granger causality from land prices to housing prices exists. Those findings indicate that Error Correction Model has been widely used to study the price determinants in residential property markets. In addition to these macroeconomic studies, the ECM has also been deployed in studying the effects of policies such as SSD on housing prices as well (Lo 2011; Craig, Hua 2011). In this study, how changes in the LTV ratio and the intro- duction of SSD influence the prices of the overall housing market and the housing sub-markets (by unit size) are to be explored.

From the previous studies on the deterministic factors of residential property prices, a linear relationship can be derived from the demand-supply equilibrium:

$L n P_{t}=\gamma_{0}+\gamma_{1} \operatorname{LnI}_{t}+\gamma_{2} \operatorname{LnGDP}_{t}+\gamma_{3} \operatorname{LnM}_{t}+\gamma_{4} \operatorname{LnBWTPI}_{t}+$ $\gamma_{5} \mathrm{LnUFA}_{t}+\gamma_{6} \mathrm{LTV}_{t}+\gamma_{7} \mathrm{SSD}+\eta_{t}$.

where: $\gamma_{\mathrm{i}}(i=1,2, \ldots, 5)$ are the estimated coefficients of the logarithms of interest rate, GDP per capita, residential property mortgage, BWTPI, and UFA. LTV ratio and SSD are assumed to have long-term influences on equilibrium prices.

In this study, the Error Correction Model (ECM) presents itself in the following equation:

$\Delta \operatorname{LnP} P_{t}=\alpha+\beta_{1} \Delta \mathrm{LnI}_{t}+\beta_{2} \Delta \mathrm{LnGDP}_{t}+\beta_{3} \Delta \mathrm{LnM}_{t}+$ $\beta_{4} \Delta \mathrm{LnBWTPI}_{t}+\beta_{5} \Delta \mathrm{LnUFA}_{t}+\beta_{6} \mathrm{ECM}_{t-1}+$ 
$\Delta \mathrm{LnP}_{t}, \Delta \mathrm{LnI}_{t}, \Delta \mathrm{LnGDP}_{t}, \Delta \mathrm{LnM}_{t}, \Delta \mathrm{LnBWTPI}_{t}$ and $\Delta \mathrm{LnUFA}_{t}$ stand for the changes from time $(t-1)$ to time $t$ in the logarithms of property price index, interest rate, GDP per capita, residential property mortgage, BWTPI, and UFA, respectively. $\Delta \mathrm{LTV}_{t}$ and $\Delta \mathrm{SSD}_{t}$ indicate the possible interruptions from the change of LTV ratio policy and SSD. The equation tries to explain how the shortterm fluctuations in property prices can be estimated by the short-term changes in both economic factors and financial-related policies. It is based upon the assumption that a proportion of the disequilibrium in the previous period would be corrected in the subsequent period, so in general the long-term equilibrium holds. $\mathrm{ECM}_{t-1}$ is the error correction term transformed from the cointegrating equation. The introduction of the error correction term can exclude the disturbances from the long-term equilibrium. Then the ECM estimation of $B_{\mathrm{i}}(i=1,2,3, \ldots)$ can be considered as the shortterm impact of changes in each selected variable on property prices only.

\section{Event study}

In addition to the ECM, an event study is also to be deployed for the analysis. The advantage of the event study approach is that it can test the shortterm impacts of sudden events with little disturnces from other determinants. To investigate the abnormal return $(A R)$ and the cumulative abnormal return $(C A R)$ accurately, the monthly property market returns $\left(R_{t}\right)$ are calculated from the property market indices. The abnormal return $(A R)$ is equal to the difference between the actual return $\left(R_{t}\right)$ and the estimated return $\left(R_{t}^{\text {est }}\right)$ :

$$
A R_{t}=R_{t}-R_{t}^{e s t} .
$$

And the cumulative abnormal return $C A R$ incurred by an event which occurs at time $t$ during $(t+m, t+n)$ is (Brown, Warner 1985):

$$
C A R(m, n)=\sum_{i=m}^{n} \mathrm{AR}_{t+i}, \mathrm{~m}<\mathrm{n},
$$

where: $m$ can be either positive or negative.

For the change in LTV ratio in October 2009, apartments valued over 20 million HKD mainly belongs to Class D $\left(100-160 \mathrm{~m}^{2}\right)$ or Class E (over $160 \mathrm{~m}^{2}$ ). In order to eliminate the impact of the change in LTV ratio in October 2001, the monthly market returns in Classes D and E from January 2002 to June 2009 ( $t=-94$ to $t=-4)$ are to be applied to construct the ARMA model for these two property sub-markets.

Similarly, for the change in LTV ratio in August 2010, the apartments valued between 12 mil- lion HKD and 20 million HKD are usually found in Classes C, D, and E (over $70 \mathrm{~m}^{2}$, average price at about 138,000 ) of the housing market. The monthly market returns in the three classes of housing from January 2002 to April $2010(t=-104$ to $t=-4)$ are to be applied to construct the ARMA model for their respective property sub-markets.

As the SSD is levied on all housing transactions in Hong Kong, the influence of SSD in November 2010 is to be examined in all five housing submarket price indices (Classes A to E). The samples of market returns from January 2000 to July 2010 $(t=-131$ to $t=-4)$ are to be chosen.

\section{DISCUSSIONS AND FINDINGS}

\section{Cointegrating analysis for long-run effects}

The ECM includes a three-step analysis. For all variables discussed in this study, according to the results obtained from the augmented Dickey-Fuller (ADF) test, they are all stationary after firstdifferencing. The cointegrating equation among these variables can be computed using EViews software. The equation itself can be rewritten as the cointegrating relationships between Property Price Index and the selected variables.

According to the definition of cointegrating relation, the coefficients can be explained as the longrun relationship between variables. Most factors are correctly signed with high level of significance as expected. Real GDP per capita is an important signal of Hong Kong's economic situations. As the economy improves, wages rise, and more people can afford the mortgage loans, which would result in higher demand for residential properties, and hence higher housing prices. Besides, a higher amount of (total) residential mortgages also indicates larger demand for private housing.

Table 4 . The cointegrating coefficients with average price index of private domestic premises

\begin{tabular}{lll}
\hline Variables & $\begin{array}{l}\text { Coeffi- } \\
\text { cients }\end{array}$ & $\begin{array}{l}\text { t-statistics (sig- } \\
\text { nificance) }\end{array}$ \\
\hline $\begin{array}{l}\text { Real interest rate/deflated } \\
\text { HIBOR+2\% }\end{array}$ & -0.1512 & -1.5180 \\
$\begin{array}{l}\text { Ln (real GDP per capita) } \\
\text { Ln (residential properties } \\
\text { mortgage) }\end{array}$ & -8.2532 & $-2.4540(* *)$ \\
$\begin{array}{l}\text { Ln (BWTPI) } \\
\text { Ln (usable floor area of } \\
\text { newly completed residen- }\end{array}$ & 2.3582 & 1.3834 \\
tial housing) & & $9.6015(* * *)$ \\
$\begin{array}{l}\text { Loan-to-value ratio } \\
\text { Special Stamp Duty }\end{array}$ & 0.2301 & 0.7252 \\
\hline * $10 \%$ significance; ** $5 \%$ significance; *** $1 \%$ significance
\end{tabular}


The findings are listed in Table 4. It suggests that, in the long run (at least 12 months after the announcement of SSD), the introduction of SSD indeed has incurred a statistically significant pressure on the average market price. This result indicates that the assumption of SSD having a longterm impact on property prices is true. People who are supposed to speculate on asset price appreciations would be more aware of the government's taxation policies and delay their resale transactions. This impact continues to be present in the whole period after the announcement of the policy.

LTV ratio is lowered when both market price and mortgage growth are high, but not significant. This relationship only reflects that the government tries to mitigate the growth in housing prices by tightening the lending restrictions on residential mortgages during the property market boom, as suggested by Goodhart and Hofmann (2007). However, there is no empirical evidence which supports the notion that this procedure has succeeded in controlling the price growth in the long-run. Even though this finding contradicts what is reported in IMF's study, it should not be viewed as a rare case in practice. In another cross-country study by Goodhart and Hofmann (2008), they conclude that there are no perfect correlations between housing price increase and LTV ratio. Housing price booms can occur even when LTV ratio is moderate or low.

Instead of land supply, this study introduces the UFA as the indicator of the supply side of the private property market. When the construction of new apartments is completed, new residential supply is offered for potential purchasers. However, in actuality, a significant positive relationship between housing supply and market price is identified. It is possible that the increase in housing demand still exceeds the increase in housing supply. Though the government tries to satisfy the residents' housing need, the amount of newly-built apartments each year does not appear to be sufficient to meet the demand from potential purchasers.

Deflated interest rate (HIBOR $+2 \%$ ) is usually viewed as one of the mortgage rate standards amongst commercial banks in Hong Kong. It is usually concluded that a negative relationship exists between interest rate and property price. Our findings indicate such negative long-run relationship between real interest rate (deflated HIBOR $+2 \%)$ and property market price, albeit insignificant. The insignificant relationship should be explained by the high rates of inflation (CPI) and low nominal interest rate since 2008. In this period, the CPI and property market price have continued to grow, but the nominal interest rate (HIBOR) has remained below $3 \%$ (from 2009 it drops below 1.5\% and now it is below 1\%). At the same time, the financial crisis came and a large amount of capital fled the stock market. The negative real interest rate has indirectly encouraged more people to invest in the property market, which is believed to be an important factor contributing to the property market boom. Then the real interest rate shows low correlations with the property market price. It

Table 5. The cointegrating coefficients for individual property submarket indices

\begin{tabular}{|c|c|c|c|c|c|}
\hline Variable coefficient & A (less than $40 \mathrm{~m}^{2}$ ) & B $\left(40-69.9 \mathrm{~m}^{2}\right)$ & $\mathrm{C}\left(70-99.9 \mathrm{~m}^{2}\right)$ & $\mathrm{D}\left(100-159.9 \mathrm{~m}^{2}\right)$ & $\mathrm{E}\left(\right.$ over $\left.160 \mathrm{~m}^{2}\right)$ \\
\hline Real interest rate & $\begin{array}{l}-0.3805 \\
(-1.4028)\end{array}$ & $\begin{array}{l}-0.1772 \\
(-1.6268)\end{array}$ & $\begin{array}{l}-0.0661 \\
(-1.6632)\end{array}$ & $\begin{array}{l}-0.0480 \\
(-1.5355)\end{array}$ & $\begin{array}{l}-0.0382 \\
(-1.7473) \\
*\end{array}$ \\
\hline Ln (real GDP per capita) & $\begin{array}{l}33.2435 \\
(5.5532) \\
* * *\end{array}$ & $\begin{array}{l}15.4182 \\
(6.6097) \\
* * *\end{array}$ & $\begin{array}{l}7.3202 \\
(8.6719) \\
* * *\end{array}$ & $\begin{array}{l}6.6315 \\
(9.9753) \\
* * *\end{array}$ & $\begin{array}{l}5.9684 \\
(13.1456) \\
* * *\end{array}$ \\
\hline Ln (mortgage amount) & $\begin{array}{l}-24.3462 \\
(-2.6616) \\
* *\end{array}$ & $\begin{array}{l}-9.5142 \\
(-2.5784) \\
* *\end{array}$ & $\begin{array}{l}-2.8720 \\
(-2.1187) \\
* *\end{array}$ & $\begin{array}{l}-2.0687 \\
(-1.9659) \\
*\end{array}$ & $\begin{array}{l}-1.2859 \\
(-1.7343) \\
*\end{array}$ \\
\hline Ln (BWTPI) & $\begin{array}{l}7.6362 \\
(1.6382)\end{array}$ & $\begin{array}{l}2.2526 \\
(1.2106)\end{array}$ & $\begin{array}{l}0.7447 \\
(1.0967)\end{array}$ & $\begin{array}{l}0.4986 \\
(0.8930)\end{array}$ & $\begin{array}{l}0.0428 \\
(0.1107)\end{array}$ \\
\hline $\begin{array}{l}\text { Ln (usable floor area of } \\
\text { newly completed residen- } \\
\text { tial housing) }\end{array}$ & $\begin{array}{l}6.6252 \\
(9.9461) \\
* * *\end{array}$ & $\begin{array}{l}2.6002 \\
(9.6153) \\
* * *\end{array}$ & $\begin{array}{l}0.8753 \\
(8.8196) \\
* * *\end{array}$ & $\begin{array}{l}0.6514 \\
(8.5076) \\
* * *\end{array}$ & $\begin{array}{l}0.3953 \\
(7.2170) \\
* * *\end{array}$ \\
\hline Loan-to-value ratio & $\begin{array}{l}0.4278 \\
(0.4949)\end{array}$ & $\begin{array}{l}0.2354 \\
(0.6737)\end{array}$ & $\begin{array}{l}0.1932 \\
(1.5277)\end{array}$ & $\begin{array}{l}0.1557 \\
(1.6045)\end{array}$ & $\begin{array}{l}0.1518 \\
(2.1999) \\
* *\end{array}$ \\
\hline Special Stamp Duty & $\begin{array}{l}-3.0580 \\
(-2.0367) \\
* *\end{array}$ & $\begin{array}{l}-1.2932 \\
(-2.1336) \\
* *\end{array}$ & $\begin{array}{l}-0.6154 \\
(-2.7954) \\
* * *\end{array}$ & $\begin{array}{l}-0.4304 \\
(-2.5496) \\
* *\end{array}$ & $\begin{array}{l}-0.3226 \\
(-2.6969) \\
* * *\end{array}$ \\
\hline
\end{tabular}

* $10 \%$ significance; $* * 5 \%$ significance; $* * * 1 \%$ significance 
indicates that changes in interest rate would not have an effective influence on the property market.

However, the results presented above still do not explain the significant yet small impact of SSD on property prices. Due to the different price movements amongst housing sub-markets, whether or not LTV ratio and SSD have different impacts on apartments of various sizes is to be tested in the following analysis (Table 5).

Similar to the overall market, the LTV ratio is lower (i.e. stronger collateral constraint) when the property price is higher, but it is not statistically significant. The coefficients indicate that the change in LTV ratio, which often correlates with property price appreciations, does not discernibly change potential buyers' propensities to purchase. Still, market demand remains strong. And buyers are generally rich in cash. The insignificant positive correlation mainly reflects the government's actions in attempt to curb the rapidly-increasing prices, by adjusting the LTV ratio. Likewise, the purchasers who are supposedly influenced by such changes the most, (i.e. those who can afford apartments over 12 million HKD) do not change their decision in housing. The relatively low mortgage rate has somehow undermined the effect of the low LTV ratio. As a result, no expected mitigated effect from the tightened LTV ratio can be observed.

Unlike the LTV ratio, SSD is a tax levied across-the-board on all classes of properties resold within two years. The long-term impacts of SSD are significant for all classes. The transaction prices for all classes of apartments are obviously influenced by the introduction of SSD. It indicates that even in a low-interest and strictly-constrained credit environment, when the monetary policy and credit policy cannot play effective roles in influencing property market prices, SSD can still be effective in slowing down the price growth by discouraging the speculation of properties. For larger size apartments (over $70 \mathrm{~m}^{2}$ ), the negative influence of SSD on prices are significant at the higher level. Besides the larger SSD payments, purchasers of larger apartments are more concerned with the resale constraints. This means that speculative activities of these larger apartments have become more prevalent. The introduction of SSD indeed slows down the quick resale transactions of these apartments and is attributed to the lower growth rates of the prices of these three classes, compared with those of Classes A and B housing units.

It is noteworthy that in all property submarkets, the cointegrating coefficients of residential mortgage are negative. Even as the price index has risen by two to threefold in the study period, the amount of mortgage has only increased by less than $70 \%$ in the same period. The financial institutes become more conservative in the real estate market boom. They tend to reduce the LTV ratio (even though it had not been made official by the government), and examine the borrowers' abilities to repay the loans. The negative relationship between residential mortgages and market price also provides another explanation as to why LTV ratio policies are not effective in curbing the growth in housing price.

\section{Error Correction Model for short-run effects}

The error correction term includes a linear combination of real interest rate, real GDP per capita, mortgage amount, BWTPI, and UFA. When excluding the impact of the error correction term, the regression coefficients of the first-order difference terms indicate the short-run effects of the selected variables (Table 6).

The introduction of SSD imposes an insignificant negative influence on overall property market prices, which is different from the findings of the IMF study (Craig, Hua 2011). And for the five housing submarkets, the short-run effects are also insignificant. SSD would exert long-run pressure on property market, but not by way of sudden change on market prices. Property transactions do not fluctuate significantly as predicted due to a policy change. The major influence from SSD is captured into the long-run effect, or the ECM terms in the Error Correction Model.

Different from IMF'S results (Craig, Hua 2011), the LTV ratio also does not show an obvious shortrun impact on residential property prices in both the overall and individual markets. The difference in the results between this study and Craig and Hua's study lies in the finding that, in this study, the long-term relationship between property prices and LTV ratio is positive. The short-term impact becomes insignificant when the long-term effect has already been captured by the cointegrating coefficient. It indicates that the LTV ratio is already a mature regulating system in Hong Kong. Changes in the LTV ratio no longer lead to a sudden shock in property prices but to a new longterm equilibrium.

Only the BWTPI and real interest rate show significant short-run impact on property price. For BWTPI, the reason relates to the connection between construction cost and property prices. In this study, no long-run impacts of construction cost on property prices are found. Sudden changes in material or wage cost, instead, are transferred to 
Table 6. ECM coefficients for overall market and submarkets

\begin{tabular}{|c|c|c|c|c|c|c|}
\hline $\begin{array}{l}\text { Variable coefficient } \\
\text { (P-value) }\end{array}$ & Overall & A & $\mathrm{B}$ & $\mathrm{C}$ & $\mathrm{D}$ & $\mathrm{E}$ \\
\hline Error correction term & $\begin{array}{l}-0.0006 \\
(-0.0956)\end{array}$ & $\begin{array}{l}-0.0002 \\
(-0.0643)\end{array}$ & $\begin{array}{l}-0.0007 \\
(-0.1165)\end{array}$ & $\begin{array}{l}-0.0081 \\
(-0.4009)\end{array}$ & $\begin{array}{l}0.0047 \\
(0.2271)\end{array}$ & $\begin{array}{l}-0.0192 \\
(-0.6400)\end{array}$ \\
\hline$\Delta$ Real interest rate & $\begin{array}{l}-0.0134 \\
(-3.0162) \\
* * *\end{array}$ & $\begin{array}{l}-0.0129 \\
(-3.0444) \\
* * *\end{array}$ & $\begin{array}{l}-0.0137 \\
(-3.0795) \\
* * *\end{array}$ & $\begin{array}{l}-0.0135 \\
(-2.3395) \\
* *\end{array}$ & $\begin{array}{l}-0.0129 \\
(-2.7164) \\
* * *\end{array}$ & $\begin{array}{l}-0.0059 \\
(-1.1668)\end{array}$ \\
\hline$\Delta \mathrm{Ln}$ (real GDP per capita) & $\begin{array}{l}0.2234 \\
(1.5188)\end{array}$ & $\begin{array}{l}0.2399 \\
(1.7019) \\
*\end{array}$ & $\begin{array}{l}0.1986 \\
(1.3544)\end{array}$ & $\begin{array}{l}0.2200 \\
(1.1266)\end{array}$ & $\begin{array}{l}0.2670 \\
(1.6363)\end{array}$ & $\begin{array}{l}0.0865 \\
(0.4696)\end{array}$ \\
\hline$\Delta \operatorname{Ln}$ (mortgage amount) & $\begin{array}{l}0.3079 \\
(0.5195)\end{array}$ & $\begin{array}{l}0.3820 \\
(0.6568)\end{array}$ & $\begin{array}{l}0.3985 \\
(0.6750)\end{array}$ & $\begin{array}{l}0.2232 \\
(0.3072)\end{array}$ & $\begin{array}{l}-0.3166 \\
(-0.5360)\end{array}$ & $\begin{array}{l}-0.1187 \\
(-0.1961)\end{array}$ \\
\hline$\Delta \operatorname{Ln}(\mathrm{BWTPI})$ & $\begin{array}{l}-0.3679 \\
(-2.6146) \\
* *\end{array}$ & $\begin{array}{l}-0.3346 \\
(-2.4471) \\
* *\end{array}$ & $\begin{array}{l}-0.3524 \\
(-2.5183) \\
* *\end{array}$ & $\begin{array}{l}-0.4176 \\
(-2.3135) \\
* *\end{array}$ & $\begin{array}{l}-0.4260 \\
(-2.9136) \\
* * *\end{array}$ & $\begin{array}{l}-0.5077 \\
(-3.2419) \\
* * *\end{array}$ \\
\hline $\begin{array}{l}\Delta \mathrm{Ln} \text { (usable floor area of } \\
\text { newly completed residential } \\
\text { housing) }\end{array}$ & $\begin{array}{l}-0.0052 \\
(-0.3974)\end{array}$ & $\begin{array}{l}-0.0012 \\
(-0.0882)\end{array}$ & $\begin{array}{l}-0.0058 \\
(-0.4404)\end{array}$ & $\begin{array}{l}-0.0160 \\
(-1.0126)\end{array}$ & $\begin{array}{l}-0.0100 \\
(-0.7911)\end{array}$ & $\begin{array}{l}-0.0132 \\
(-1.0337)\end{array}$ \\
\hline Loan-to-value ratio & $\begin{array}{l}0.0024 \\
(0.1179)\end{array}$ & $\begin{array}{l}-0.0004 \\
(-0.0220)\end{array}$ & $\begin{array}{l}0.0048 \\
(0.2309)\end{array}$ & $\begin{array}{l}-0.0006 \\
(-0.0237)\end{array}$ & $\begin{array}{l}0.0032 \\
(0.1462)\end{array}$ & $\begin{array}{l}-0.0053 \\
(-0.2265)\end{array}$ \\
\hline Special Stamp Duty & $\begin{array}{l}-0.0146 \\
(-0.4414)\end{array}$ & $\begin{array}{l}-0.0205 \\
(-0.6365)\end{array}$ & $\begin{array}{l}-0.0156 \\
(-0.4736)\end{array}$ & $\begin{array}{l}0.0024 \\
(0.0576)\end{array}$ & $\begin{array}{l}-0.0113 \\
(-0.3274)\end{array}$ & $\begin{array}{l}0.0238 \\
(0.0364)\end{array}$ \\
\hline
\end{tabular}

$* 10 \%$ significance; ${ }^{* *} 5 \%$ significance; $* * * 1 \%$ significance

property prices in a short period of time. Corresponding to previous studies, an increase in real interest rate indeed gives an impulse to market prices in a short run, but not in the long run.

\section{Event study for the Loan-to-value ratio and Special Stamp Duty}

In this section, the short-run impacts of LTV ratio and SSD are to be reexamined via an event study. To further explain speculative behaviours in the property market (and the government, in response, is supposed to restrict these transactions by means of LTV ratio and SSD), a supplementary discussion is to be provided.

Table 7 presents the ARs of Class D flats and Class E flats when the LTV ratio for properties valued over 20 million HKD was reduced from $70 \%$ to $60 \%$ in October 2009 . The CARs in $(-1,1)$ are also provided. Although the scale of ARs and CARs are about $3-5 \%$, the standard error in the sample period is over $2.5 \%$ (and over $3 \%$ for Class E flats), and the t-statistics for the ARs and CARs are smaller than the $5 \%$ critical values. The high volatility of prices in the luxury property market impairs the impact of the adjusted LTV ratio.

Table 7. Event study results for the adjustment of Loan-to-value ratio in Oct 2009

\begin{tabular}{lll}
\hline & AR & CAR $(0,2)$ \\
\hline Class D & $-3.34 \%$ & $-3.68 \%$ \\
Class E & $-5.52 \%$ & $-6.02 \%$ \\
Affected markets & $-4.43 \%$ & $-4.85 \%$ \\
\hline
\end{tabular}

The second adjustment of LTV ratio, for properties valued between 12 and 20 million HKD, took place in August 2010. This time, the lowered LTV ratio shows even less influence on property prices (Table 8).

Table 8. Event study results for the adjustment of Loan-to-value ratio in Aug 2010

\begin{tabular}{lll}
\hline & AR & CAR(0,2) \\
\hline Class C & $0.52 \%$ & $-3.05 \%$ \\
Class D & $-0.69 \%$ & $-3.55 \%$ \\
Class E & $-1.90 \%$ & $-4.68 \%$ \\
Affected markets & $-0.69 \%$ & $-3.76 \%$ \\
\hline
\end{tabular}

It is not surprising that the adjustment of LTV ratio in October 2009 and then in August 2010 has not resulted in significantly lower property prices as expected. Although from Oct 2008 to Oct 2009, the stock market in Hong Kong had experienced a $47 \%$ growth (from 15,000 to 22,000 ), it was then recognized as the result of the market-stimulating policies by the US and Chinese governments. The stock price index had just rebounded to the levels prior to the financial crisis. However, no further positive news regarding the economic outlook had been released in the following several years, which limited the upside potential of the stock market. In fact, the stock market index had fluctuated between 20,000 and 24,000 in the following 3 years.

On the other hand, a $12.9 \%(13.8 \%)$ rise in prices was recorded for the Class D (Class E) residential properties, from October 2008 to October 
2009. The quantitative easing policy in the US and China, the low mortgage rate in Hong Kong, and the pessimistic attitude to the stock market had led to the inflow of capital to the property market. With the LTV ratio at $70 \%$, an investor can achieve annual returns of about $36 \%$ (Class D) and 39\% (Class E) respectively, on the basis of mortgages at $3 \%$ per annum. With the LTV ratio at $60 \%$, however, the annual returns reduce to $25 \%$ (Class D) and $27.5 \%$ (Class E) respectively. Nonetheless, luxury properties are still an attractive investment choice for speculators. From October 2009 to August 2010, the real growth rates in this market were $14.5 \%$ (Class D) and 14.4\% (Class E), which further supports the investors' confident outlook that the upside potential of luxury housing units can offset the deduction in annual return due to the change in LTV ratio. As a result, the adjustment in August 2010 shows even less influence on property prices.

For the introduction of SSD in Oct 2010, the short-term impacts on different classes of housing are summarized in Table 9. The standard error varies from $2.28 \%$ (Class A) to $3.11 \%$ (Class E). Both the t-statistics of ARs and of CARs are smaller than the $5 \%$ critical values.

Table 9. Event study results for the introduction of Special Stamp Duty in Nov 2010

\begin{tabular}{lll}
\hline & AR & CAR(0,2) \\
\hline Class A & $1.15 \%$ & $3.30 \%$ \\
Class B & $2.20 \%$ & $3.71 \%$ \\
Class C & $2.35 \%$ & $2.12 \%$ \\
Class D & $0.88 \%$ & $3.03 \%$ \\
Class E & $1.47 \%$ & $-0.79 \%$ \\
Affected markets & $1.61 \%$ & $2.27 \%$ \\
\hline
\end{tabular}

When the Hong Kong government began to impose the SSD on the property market, the nominal overall market index had experienced an annual increase of $15.2 \%$ and $21.6 \%$ in the past two years. A bullish investor, whose confidence is strong enough, would still choose to purchase a property, only to resell it slightly later to avoid the payment of the high-level SSD. The bullish investor believes that his investment could still appreciate even after two years (or much higher than $5 \%$ return in the following year, which can cover the SSD). Only the neutral or bearish investors would become more discreet in their purchase behaviours. At that moment, the number of bullish investors in the market is much more than that of neutral or bearish investors (which is proved by the market trend in 2011 and 2012). Therefore, market demand, in the short-run, would not be obviously distorted by the imposition of SSD.
It should be noted that the rate of SSD is different from the common stamp duty (or transfer tax), which is a progressive tax imposed on property transactions. Even if the investor tries to resell his property at a lower price, the rate of SSD would remain constant. As a result, the transaction prices would not cluster in any price level. Different from the case of progressive transfer tax (Best, Kleven 2012; Kopczuk, Munroe 2015), transactions would not be disturbed because of its price level. Hence, no sudden drop would occur due to the SSD in the short run.

Of course, the investors' attitudes are not inflexible. If the market price has experienced a continuous rise in the past several years, the number of neutral or bearish investors in the market would increase gradually. The declining market demand in the long-run would lead to an observable decrease in market price.

\section{CONCLUSION}

This study has investigated the possible impacts of Loan-to-value ratio and Special Stamp Duty on residential property prices in Hong Kong. Of the two policy measures, SSD is not a commonly-used tool for stabilizing property price. Because of that, only a few studies have been conducted to demonstrate the impact of this special transfer tax (the tax rate is based on the holding period) on market prices. This study has provided new findings for the influence of LTV ratio and SSD policies on Hong Kong's property market, when the real interest rate stays low and the amount of property mortgages grows much slower than property market prices. This study, using the Error Correction Model and event study analysis, has focused on both long- and short-term effects of LTV ratio and SSD on prices of housing units in different submarkets (by unit size), which has been overlooked in previous studies.

Our findings show that, in the long-run, property prices in both the general market and the submarkets are not influenced by changes in the LTV ratio (or stronger collateral constraint). Despite the government's intention to curb property price appreciations by means of LTV ratio adjustments, market participants' propensities to buy do not appear to be affected. On the other hand, the SSD is found to exert statistically significant pressure on property prices of high-value properties (such as apartments larger than $70 \mathrm{~m}^{2}$ ), at a higher level than of smaller housing units (smaller than $70 \mathrm{~m}^{2}$ ). However, in the short-run, there is no 
evidence suggesting that either LTV ratio or SSD cause housing price to fall. Both types of policies do not provide a direct shock to market prices as real interest rate does.

These findings show remarkable differences from to those in previous studies. For the longterm effects, this study has shown that, unlike previous studies (Crowe et al. 2013; Kuttner, Shim 2013), the LTV ratio policy is not an effective tool to stabilize the rapid market price growth. The impacts of SSD on different housing submarkets (by unit size) in Hong Kong have been clearly demonstrated in this study, which extends the findings reported in Lo's study (2011) on the Singaporean housing market. This study has also provided a more detailed analysis for a better understanding as to how the SSD affects the prices of apartments of different sizes, compared with the analysis in Kuttner and Shim (2013). For the short-term effect, the finding in this study is not in line with Craig and Hua's (2011) conclusion that SSD should push up property prices in the short run.

In summary, those measures are not effective in keeping the housing price in check for Hong Kong residents. Some policy implications can be drawn from the above conclusions. The government should not try to disturb the market prices by introducing new SSD measures. The tax structure of the present SSD measures should also be reviewed (and possibly revised) to reduce the tax burden for potential home purchasers. It is suggested that the revenue obtained from SSD should be used to increase public housing supply. LTV ratio is also not an effective tool to slow down the upward property price movements. To address the housing affordability issue among Hong Kong residents, the critical problem is how to supply more housing in both the public and private sectors. On the other hand, on February 22, 2014, the Legislative Council passed the Stamp Duty (Amendment) Bill on the third reading, and SSD would become a formal policy tool for regulating the property market in the future. This study would provide an important reference on how to execute the law in the future, in which both the government and the public would be interested.

\section{ACKNOWLEDGEMENT}

The authors wish to express appreciation to the anonymous reviewers for their valuable comments on this paper. This study was funded by the Hong Kong Polytechnic University's Internal Grants (4ZZC8, B-Q42Q (PolyU 152059/14E) and 4-941D).

\section{REFERENCES}

Adams, Z.; Füss, R. 2010. Macroeconomic determinants of international housing markets, Journal of Housing Economics 19(1): 38-50. https://doi.org/10.1016/j. jhe.2009.10.005

Ahuja, A.; Nabar, M. 2011. Safeguarding banks and containing property booms: cross-country evidence on macroprudential policies and lessons from Hong Kong SAR, IMF Working Paper (No. 11/284), International Monetary Fund, 1-26.

Benito, A. 2006. The down-payment constraint and UK housing market: does the theory fit the facts?, Journal of Housing Economics 15(1): 1-20. https://doi.org/10.1016/j.jhe.2006.02.001

Benjamin, J. D.; Coulson, N. E.; Yang, S. X. 1993. Real estate transfer taxes and property values: the Philadelphia story, Journal of Real Estate Finance and Economics 7(2): 151-157. https://doi.org/10.1007/ BF01258324

Best, M.; Kleven, H. J. 2012. Property transaction taxes and the housing market: evidence from notches and housing stimulus in the UK, Working Paper. London School of Economics.

Brown, S. J.; Warner, J. B. 1985. Using daily stock returns: the case of event studies, Journal of Financial Economics 14(1): 3-31. https://doi.org/10.1016/0304405X(85)90042-X

Case, K. E.; Shiller, R. J. 2003. Is there a bubble in the housing market?, Brookings Papers on Economic Activity 2003(2): 299-362. https://doi.org/10.1353/ eca.2004.0004

Chen, M. C.; Chang, C. O.; Yang, C. Y.; Hsieh, B. M. 2012. Investment demand and housing prices in an emerging economy, Journal of Real Estate Research 34(3): 345-373.

Chen, M. C.; Patel, K. 2002. An empirical analysis of determination of housing prices in the Taipei area, Taiwan Economic Review 30(4): 563-596.

Claessens, S.; Ghosh, S. R.; Mihet, R. 2013. Macroprudential policies to mitigate financial system vulnerabilities, Journal of International Money and Finance 39: 153-185. https://doi.org/10.1016/j.jimonfin.2013.06.023

Craig, R. S.; Hua, C. 2011. Determinants of property prices in Hong Kong SAR: implications for policy, IMF Working Paper (No. 11-277), International Monetary Fund.

Crowe, C.; Dell'Ariccia, G.; Igan, D.; Rabanal, P. 2013. How to deal with real estate booms: lessons from country experiences, Journal of Financial Stability 9(3): 300-319. https://doi.org/10.1016/j. jfs.2013.05.003

Dachis, B.; Duranton, G.; Turner, M. A. 2012. The effects of land transfer taxes on real estate markets: evidence from a natural experiment in Toronto, Journal of Economic Geography 12(2): 327-354. https://doi. org/10.1093/jeg/lbr007

Dipasquale, D. 1999. Why don't we know more about housing supply?, Journal of Real Estate Finance and Economics 18(1): 9-23. https://doi. org/10.1023/A:1007729227419 
Du, H.; Ma, Y.; An, Y. 2011. The impact of land policy on the relation between housing and land prices: evidence from China, Quarterly Review of Economics and Finance 51(1): 19-27. https://doi.org/10.1016/j. qref.2010.09.004

Engle, R. F.; Granger, C. W. 1987. Co-integration and error correction: representation, estimation, and testing, Econometrica 55(2): 251-276. https://doi.org/10.2307/1913236

Genesove, D.; Mayer, C. 2001. Loss aversion and seller behavior: evidence from the housing market, Quarterly Journal of Economics 116(4): 1233-1260. https://doi.org/10.1162/003355301753265561

Glindro, E. T.; Subhanij, T.; Szeto, J.; Zhu, H. 2008. Determinants of house prices in nine Asia-Pacific economies, BIS Working Paper (No. 263), Bank of International Settlements. https://doi.org/10.2139/ ssrn. 1333646

Goodhart, C.; Hofmann, B. 2007. House prices and the macroeconomy: implications for banking and price stability. Oxford University Press.

Goodhart, C.; Hofmann, B. 2008. House prices, money, credit, and the macroeconomy, Oxford Review of Economic Policy 24(1): 180-205. https://doi.org/10.1093/ oxrep/grn009

Ho, M. H. C.; Kwong, T. M. 2002. Speculation and property price: chicken and egg paradox, Habitat International 26(3): 347-361. https://doi.org/10.1016/ S0197-3975(02)00012-7

Hui, E. C. M. 2001. Planning and development control through lease conditions, Habitat International 25(4): 599-615. https://doi.org/10.1016/S01973975(01)00028-5

Hui, E. C. M.; Gu, Q. 2009. Study of Guangzhou house price bubble based on state-space model, International Journal of Strategic Property Management 13(4): 287-298. https://doi.org/10.3846/1648715X.2009.13.287-298

Hui, E. C.; Lam, M. C.; Ho, V. S. 2006. Market disequilibrium and urban land shortages: analysis of policy and patterns in Hong Kong, Journal of Urban Planning and Development 132(2): 80-88. https://doi. org/10.1061/(ASCE)0733-9488(2006)132:2(80)

Hui, E. C.; Soo, J. A. 2002. Development conditions and supply of housing: evidence from Hong Kong, Journal of Urban Planning and Development 128(3): 105-138. https://doi.org/10.1061/(ASCE)07339488(2002)128:3(105)

Immergluck, D.; Smith, G. 2005. Measuring the effect of subprime lending on neighborhood foreclosures evidence from Chicago, Urban Affairs Review 40(3): 362-389. https://doi.org/10.1177/1078087404271444

Kopczuk, W.; Munroe, D. J. 2015. Mansion tax: the effect of transfer taxes on the residential real estate mar- ket, American Economic Journal: Economic Policy 7(2): 214-257. https://doi.org/10.1257/pol.20130361

Kuttner, K. N.; Shim, I. 2013. Can non-interest rate policies stabilize housing markets? Evidence from a panel of 57 economies. NBER Working Paper (No. w19723), National Bureau of Economic Research. https://doi.org/10.3386/w19723

Lamont, O.; Stein, J. C. 1999. Leverage and house-price dynamics in US cities, RAND Journal of Economics 30(3): 498-514.

Lo, K. C. 2011. The driving forces behind the recent housing market development in Hong Kong: fundamentals? bubbles? policy? Master's thesis. Lingnan University, Hong Kong. https://doi.org/10.14793/econ_etd.7

Lum, S. K. 2002. Market fundamentals, public policy and private gain: house price dynamics in Singapore, Journal of Property Research 19(2): 121-143. https://doi.org/10.1080/09599910210125232

McQuinn, K.; O'Reilly, G. 2008. Assessing the role of income and interest rates in determining house prices, Economic Modelling 25(3): 377-390. https://doi.org/10.1016/j.econmod.2007.06.010

Ortalo-Magné, F.; Rady, S. 2006. Housing market dynamics: on the contribution of income shocks and credit constraints, Review of Economic Studies 73(2): 459-485. https://doi.org/10.1111/j.1467937X.2006.383_1.X

Stein, J. C. 1995. Prices and trading volume in the housing market: a model with down-payment effects, Quarterly Journal of Economics 110(2): 379-406.

Wang, S.; Chan, S. H.; Xu, B. 2012. The estimation and determinants of the price elasticity of housing supply: evidence from China, Journal of Real Estate Research 34(3): 311-344.

Wei, Y.; Lam, P. T.; Chiang, Y. H.; Leung, B. Y. 2014. The effects of monetary policy on real estate investment in China: a regional perspective, International Journal of Strategic Property Management 18(4): 368379. https://doi.org/10.3846/1648715X.2014.971087

Wong, J. T. Y.; Hui, E. C. M.; Seabrooke, W.; Raftery, J. 2005. A study of the Hong Kong property market: housing price expectations, Construction Management and Economics 23(7): 757-765. https://doi.org/10.1080/01446190500127260

Wong, T. C.; Fong, T.; Li, K. F.; Choi, H. 2011. Loan-tovalue ratio as a macroprudential tool - Hong Kong's experience and cross-country evidence, Systemic Risk, Basel III, Financial Stability and Regulation. https://doi.org/10.2139/ssrn.1768546

Wong, T. Y. J.; Hui, E. C. M.; Seabrooke, W. 2003. The impact of interest rates upon housing prices: an empirical study of Hong Kong's market, Property Management 21(2): 153-170. https://doi.org/10.1108/02637470310478891 